Jambura Health and Sport Journal

Vol. 4, No. 1, Februari 2022

p-ISSN: 2654-718X, e-ISSN: 2656-2863

\title{
PEMANFAATAN LAYANAN SISTEM INFORMASI E-PUSKESMAS DENGAN MENGGUNAKAN METODE PIECES
}

\section{UTILIZATION OF E-PUSKESMAS INFORMATION SYSTEM SERVICES USING THE PIECES METHOD}

\author{
${ }^{1 *}$ Sylva Flora Ninta Tarigan, ${ }^{2}$ Tri Septian Maksum \\ ${ }^{1 *}$ Bagian Administrasi dan Kebijakan Kesehatan, Jurusan Kesehatan Masyarakat, Universitas Negeri Gorontalo \\ ${ }^{2}$ Bagian Kesehatan Lingkungan, Jurusan Kesehatan Masyarakat, Universitas Negeri Gorontalo
}

Kontak koresponden: floraninta@gmail.com

\begin{abstract}
ABSTRAK
Proses pelayanan di setiap puskesmas membutuhkan waktu yang lama apabila dikerjakan secara manual, sehingga perlu manajemen yang berbasis web, salah satunya dengan menggunakan aplikasi e-puskesmas. E-Puskesmas merupakan wujud dari penerapan sistem informasi manajemen puskesmas yang mampu memberikan kontribusi besar dalam pelayanan prima kepada pasien. Tujuan penelitian untuk mengetahui pemanfaatan layanan sistem informasi epuskesmas dengan menggunakan metode PIECES (performance, information, economics, control, efficiency, service). Jenis penelitian adalah survei deskriptif. Sampel penelitian sebanyak 29 orang tenaga kesehatan yang diperoleh menggunakan teknik total sampling. Data dikumpul menggunakan kuesioner, dan dianalisis secara deskriptif. Hasil penelitian menunjukan bahwa aspek dengan kategori baik yaitu performance (51.7\%), information (55.2\%), dan service (55.2\%), sedangkan aspek dengan kategori kurang baik yaitu economics (51.7\%), control (72.4\%), dan efficiency (55.2\%). Disarankan bagi pihak Puskesmas Kota Barat disarankan untuk menerapkan layanan e-puskesmas sesuai dengan Keputusan Menteri Kesehatan No. 128/Menkes/SK/II/2014.
\end{abstract}

Kata Kunci: Sistem Informasi; e-Puskesmas; PIECES

\section{ABSTRACT}

The service process at each puskesmas takes a long time if it is done manually, so it needs webbased management, one of which is by using the e-puskesmas application. E-Puskesmas is a manifestation of the implementation of a puskesmas management information system that is able to make a major contribution to excellent service to patients. The purpose of the study was to determine the utilization of e-Puskesmas information system services using the PIECES method (performance, information, economics, control, efficiency, service). This type of research is a descriptive survey. The research sample was 29 health workers who were obtained using a total sampling technique. Data were collected using a questionnaire and analyzed descriptively. The results showed that aspects with good categories were performance (51.7\%), information (55.2\%), and service (55.2\%), while aspects with less good categories were economics (51.7\%), control (72.4\%), and efficiency (55.2\%). It is recommended for the West City Health Center to implement e-Puskesmas services in accordance with the Decree of the Minister of Health No. 128/Menkes/SK/II/2014.

Keywords: Information Systems; e-Puskesmas; PIECES 


\section{Pendahuluan}

Sistem informasi manajeman puskesmas merupakan suatu aplikasi manajemen puskesmas dimana fungsi utamanya adalah mengelola data pasien mulai dari pendaftaran, registrasi, pemeriksaan (diagnosis) serta pengobatan pasien (Fikri, 2019). Data yang sudah diinput ditampung dalam sebuah database yang nantinya akan dikatagorikan sesuai dengan parameter untuk kebutuhan laporan, seperti laporan kunjungan harian, cara pembayaran, jenis penyakit serta laporan lainnya yang dibutuhkan dalam manajemen puskesmas (Kepmenkes, 2014). Manajemen puskesmas jika dilakukan dengan secara manual akan mengakibatkan proses pelayanan membutuhkan waktu yang lama, terutama pada saat proses pencarian nomor rekam medis pasien yang tidak membawa kartu berobat (Fitriana et al., 2020). Oleh karena itu, dalam kegiatan manajemen puskesmas sangatlah penting untuk menggunakan layanan yang berbasis web (Christanti dan Pratiwi, 2016).

Aplikasi yang digunakan dalam pelayanan kesehatan dasar kepada masyarakat ditiap-tiap puskesmas salah satunya menggunakan aplikasi e-Puskesmas (Haryani \& Satriadi, 2019). EPuskesmas merupakan wujud dari penerapan sistem informasi manajemen puskesmas yang mampu memberikan kontribusi yang sangatlah besar dalam memberikan pelayanan yang prima kepada pasien (Dona et al., 2019). Dengan e-Puskesmas pencatatan dan pendataan pasien dilakukan secara elektronik. Layanan aplikasi e-Puskesmas juga semakin memudahkan dinas kesehatan dalam memonitor data kesehatan masyarakat (Putra, 2018).

Analisis kebutuhan sistem menitikberatkan pada bagaimana mengidentifikasi kelemahan yang dijumpai pada sistem lama. Untuk mempermudah cara melakukannya, ditawarkan cara analisis dengan kerangka PIECES yang menguraikan ke dalam enam fokus analisis kelemahan yaitu performance, information, economics, control, eficiency dan service. Hasil analisis PIECES merupakan dokumen kelemahan sistem yang menjadi rekomendasi untuk perbaikan-perbaikan yang harus dibuat pada sistem yang akan dikembangkan lebih lanjut atau untuk perbaikan dari sistem sebelumnya (Fatta, 2007; Ramadhan \& Kusumaningtyas, 2021).

Penelitian yang dilakukan oleh (Wulandari, 2009) di wilayah kerja Dinas Kesehatan Kota Semarang bahwa penerapan sistem informasi manajeman puskesmas mengalami kendala yaitu kebutuhan informasi yang terus berkembang, sehingga diharapkan harus terus dikembangkan, namun kenyataannya pengembangannya tidak bisa dilakukan setiap saat. Penelitian lain oleh (Inggarputri, 2009) di Puskesmas wilayah Kabupaten Blora bahwa masih ditemukan kendala dari hasil evaluasi sistem informasi manajeman puskesmas dengan menggunakan metode PIECES yakni dari aspek performance, information, dan efficiency. Penelitian lain juga menyebutkan dalam hasil penelitiannya di Kabupaten Bantul, dimana masih ditemukan hambatan penerapan sistem informasi manajeman puskesmas yaitu pada keterbatasan sumber daya manusia (Widodo, 2013).

Berdasarkan hasil wawancara dengan pihak Dinas Kesehatan Kota Gorontalo bahwa puskesmas se-Kota Gorontalo pada prinsipnya sudah memanfaatkan E-puskesmas sejak Tahun 2017, tetapi penerapannya di tiap puskesmas belum maksimal. Idealnya SDM, data, teknologi 
dan proses pengolahan termasuk dalam komponen fisik dari sebuah sistem informasi manajemen. Komponen ini mendukung dalam menghasilkan informasi yang tepat, akurat dan dapat dipertanggungjawabkan serta membantu dalam proses pengambilan keputusan (Subektianto et al., 2018).

Puskesmas Kota Barat merupakan salah satu puskesmas rawat jalan yang ada di Kota Gorontalo yang memiliki peringkat akreditas tertinggi (akreditasi paripurna). E-puskesmas telah digunakan oleh Puskesmas Kota Barat sejak Tahun 2017. Oleh karena Puskesmas Kota Barat sudah terakreditasi paripurna, maka diharapkan penerapan e-puskesmas di Puskesmas Kota Barat diterapkan dengan baik dan dapat memberikan kontribusi bagi puskesmas dalam peningkatan efektifitas dan efsisiensi pelayanan kesehatan. Penelitian ini bertujuan untuk mengetahui pemanfaatan layanan sistem informasi e-puskesmas dengan menggunakan metode PIECES.

\section{Metode}

Penelitian ini dilaksanakan di Puskesmas Kota Barat, Kota Gorontalo pada Bulan April 2021. Penelitian ini termasuk dalam jenis penelitian survei deskritif untuk menggambarkan dan menginterpretasi objek sesuai dengan apa adanya, dengan tujuan menggambarkan secara sistematis fakta dan karakteristik objek yang diteliti (Sugiyono, 2018). Populasi dalam penelitian ini yakni semua tenaga kesehatan di Puskesmas Barat yang bekerja di poli umum, poli gigi, poli $\mathrm{KIA} / \mathrm{KB}$, apotek, dan bagian konseling, dengan jumlah 29 orang. Sampel dalam penelitian ini sama dengan jumlah populasi yakni berjumlah 29 orang, dengan menggunakan teknik total sampling. Analisis data menggunakan bantuan komputer (program SPSS), dikaji secara deskriptif dan selanjutnya dinarasikan.

\section{Hasil}

a. Karakteristik Responden

Tabel 1. Karakteristik Responden

\begin{tabular}{ccc}
\hline Karakteristik responden & \multicolumn{2}{c}{ Jumlah } \\
\cline { 2 - 3 } & $\mathrm{n}$ & $\%$ \\
\hline Kelompok umur (tahun) : & & \\
$22-29$ & 10 & 34.5 \\
$30-37$ & 6 & 20.7 \\
$38-45$ & 6 & 20.7 \\
$46-53$ & 7 & 24.1 \\
\hline Jenis kelamin : & & \\
Laki-laki & 23 & 79.3 \\
Perempuan & 6 & 20.7 \\
\hline Pendidikan terakhir : & & \\
Diploma III & 17 & 58.6 \\
Strata I & 12 & 41.4 \\
\hline Jenis pekerjaan : & & \\
PNS & 19 & 65.5 \\
Kontrak & 1 & 3.4 \\
Honorer & 9 & 31.1 \\
\hline
\end{tabular}


Sumber : Data Primer, 2021

Berdasarkan tabel, responden dalam penelitian ini paling banyak dalam kelompok umur 22-29 tahun (34.5\%), berjenis kelamin laki-laki (79.3\%), berpendidikan diploma III (58.6\%), dan bekerja sebagai PNS (65.5\%).

b. Pemanfaatan Layanan Sistem Informasi E-Puskesmas Dengan Menggunakan Metode PIECES

Tabel 2. Pemanfaatan Layanan E-Puskesmas di Puskesmas Kota Barat

\begin{tabular}{lcccc}
\hline \multirow{2}{*}{ Aspek yang dinilai } & \multicolumn{2}{c}{ Baik } & \multicolumn{2}{c}{ Kurang Baik } \\
\cline { 2 - 5 } & $\mathrm{n}$ & $\%$ & $\mathrm{n}$ & $\%$ \\
\hline Performance & 15 & 51.7 & 14 & 48.3 \\
\hline Information & 16 & 55.2 & 13 & 44.8 \\
\hline Economics & 14 & 48.3 & 15 & 51.7 \\
\hline Control & 8 & 27.6 & 21 & 72.4 \\
\hline Efficiency & 13 & 44.8 & 16 & 55.2 \\
\hline Service & 16 & 55.2 & 13 & 44.8 \\
\hline \multicolumn{2}{c}{ Sumber : Data Primer } & 2021
\end{tabular}

Berdasarkan tabel, diperoleh bahwa pemanfaatan layanan sistem informasi e-puskesmas di Puskesmas Kota Barat dilihat dari aspek performance $(51,7 \%)$, information $(55,2 \%)$ dan service $(55,2 \%)$ termasuk dalam kategori baik, sedangkan dari aspek economics $(51,7 \%)$, control $(72,4 \%)$ dan efficiency $(55,2 \%)$ termasuk dalam kategori kurang baik.

\section{Pembahasan}

Metode PIECES adalah metode analisis sebagai dasar untuk memperoleh pokok-pokok permasalahan yang lebih spesifik. Dalam menganalisis sebuah sistem, biasanya akan dilakukan terhadap beberapa aspek antara lain adalah kinerja (performance), informasi (information), ekonomi (economics), keamanan aplikasi (control), efisiensi (efficiency) dan pelayanan pelanggan (service) (Maulana \& Salim, 2021; Pratiwi \& Susanti, 2021; Prayogi et al., 2021).

Performance merupakan variabel pertama dalam metode analisis PIECES. Dimana memiliki peran penting untuk menilai apakah proses atau prosedur yang ada masih mungkin ditingkatkan kinerjanya, dan melihat sejauh mana dan seberapa handalkah suatu sistem informasi dalam berproses untuk menghasilkan tujuan yang diinginkan (Muliansah \& Budihartanti, 2020).

Hasil penelitian menunjukkan bahwa e-puskesmas secara performance dengan pilihan menu dan navigasi yang tersedia memudahkan tenaga kesehatan dalam menerapkan sistem informasi manajemen puskesmas, sehingga dari aspek performance termasuk dalam kategori baik. Namun e-puskesmas di Puskesmas Kota Barat belum diterapkan dalam bidang lainnya, seperti di poli gigi, poli KIA/KB, bagian apotek dan bagian konseling. Hal ini dikarenakan keterbatasan sarana prasarana berupa komputer dalam menunjang penerapan e-puskesmas. Hasil ini sejalan dengan penelitian (Muliansah \& Budihartanti, 2020) yang menunjukan bahwa hasil pemanfaatan e-Puskesmas di loket pendaftaran pada Puskesmas Kecamatan Pademangan, 
perhitungan jumlah rata- rata tingkat kepuasan diperoleh bernilai 4.10 pada domain performance dan bila dipadukan dengan tingkat kepuasan menurut Kaplan dan Norton, maka dapat disimpulkan bahwa tingkat diperoleh rata-rata tingkat kepuasan berdasarkan domain kepuasan pengguna terhadap e-Puskesmas termasuk dalam kategori puas. Penelitian ini juga sejalan dengan penelitian (Fikri, 2019) yaitu penerapan sistem informasi manajemen puskesmas dari 42 responden 27 orang (64.3\%) diantaranya menyatakan baik, sedangkan dari 15 orang (35.7\%) menyatakan tidak baik.

Relevansi informasi, dimana informasi yang dihasilkan sesuai dengan kebutuhan Informasi menilai apakah prosedur yang ada saat ini masih diperbaiki sehingga kualitas informasi yang dihasilkan menjadi semakin baik. Yang dimaksud kualitas informasi yang semakin baik adalah semakin relevan, akurat, dan lengkap serta disajikan secara tepat waktu (Fatta, 2007). Information menilai apakah prosedur yang ada saat ini masih dapat diperbaiki sehingga kualitas informasi yang dihasilkan menjadi semakin baik. Informasi yang disajikan haruslah benar-benar mempunyai nilai yang berguna (Muliansah \& Budihartanti, 2020).

Hasil penelitian menunjukkan bahwa dari aspek information penerapan e-puskesmas di Puskesmas Kota Barat termasuk dalam kategori baik yaitu mudah digunakan, mudah untuk dipelajari, dan output yang dibuat mudah untuk dibaca. Namun dalam proses input data di epuskesmas masih rumit, karena tidak semua data mengenai pasien maupun data puskesmas dapat di input dalam aplikasi e-puskesmas, hanya di bagian pendaftaran yang diterapakan SIMPUS dan laporan yang diinput per bulan hanya LB1 (Laporan bulanan data kesakitan), dan yang tidak dapat diinput dalam aplikasi e-puskesmas yaitu pemerikasaan medis, pelayanan resep, pengeluaran obat pasien, pelayanan laboratorium, tindakan dokter, dan e-puskesmas tidak dapat menginput laporan bulanan seperti LB2 (Laporan penggunaan obat), LB3 (Laporan puskesmas yang berisi perbaikan gizi, laporan hasil program KIA/KB) dan LB4 (Laporan kegiatan puskesmas, laporan pelayanan gigi, dan mulut, laporan jumlah kegiatan kesling dan penyuluhan).

Hasil penelitian ini sejalan dengan penelitian (Muliansah \& Budihartanti, 2020) yang menunjukan bahwa hasil pemanfaatan e-Puskesmas di loket pendaftaran pada Puskesmas Kecamatan Pademangan, perhitungan jumlah rata- rata tingkat kepuasan diperoleh bernilai 4.16 pada domain information dan bila dipadukan dengan tingkat kepuasan menurut Kaplan dan Norton, maka dapat disimpulkan bahwa tingkat diperoleh rata-rata tingkat kepuasan berdasarkan domain kepuasan pengguna terhadap e-Puskesmas termasuk dalam kategori puas.

Analisis ekonomi merupakan penilaian sistem atau biaya dan keuntungan yang akan didapatkan dari sistem yang diterapkan. Hal yang harus diperhatikan dalam analisis ini adalah biaya dan keuntungan. Biaya meliputi biaya tidak diketahui, biaya tidak dapat dilacak ke sumber, dan biaya terlalu tinggi. Sedangkan untuk keuntungan meliputi pasarpasar baru dapat dieksplorasi, pemasaran ini dapat diperbaiki, dan pesanan-pesanan dapat ditingkatkan (Fatta, 2007).

Hasil penelitian menunjukkan bahwa dari aspek economics penerapan e-puskesmas di Puskesmas Kota Barat termasuk dalam kategori kurang baik. Hal ini karena aplikasi epuskesmas hanya digunakan di bidang pelayanan saja oleh karena keterbatasan alat komputer 
untuk digunakan oleh bidang lain. Selain itu, aplikasi e-puskesmas belum dapat menginput data sesuai dengan Kemenkes No. 128/Menkes/SK/II/2014. Hasil ini tidak sejalan dengan penelitian (Inggarputri, 2009) yang menunjukkan bahwa hasil evaluasi penerapan sistem informasi manajemen puskesmas berbasis komputer di puskesmas wilayah Kabupaten Blora dari aspek economics dinilai memiliki biaya yang rendah dan manfaat yang banyak. Hasil penelitian ini juga tidak sejalan dengan penelitian (Muliansah \& Budihartanti, 2020) yang menunjukan bahwa hasil pemanfaatan e-Puskesmas di loket pendaftaran pada Puskesmas Kecamatan Pademangan, perhitungan jumlah rata- rata tingkat kepuasan diperoleh bernilai 4.19 pada domain economics dan bila dipadukan dengan tingkat kepuasan menurut Kaplan dan Norton, maka dapat disimpulkan bahwa tingkat diperoleh rata-rata tingkat kepuasan berdasarkan domain kepuasan pengguna terhadap e-Puskesmas termasuk dalam kategori puas.

Control yaitu mekanisme yang mengontrol atau melindungi program dan data.Untuk meningkatkan kinerja sistem, mencegah atau mendeteksi kesalahan sistem serta menjamin keamanan data dan informasi maka dipasang sebuah kontrol (Al-Fatta, 2007). Control menilai apakah prosedur yang ada saat ini masih dapat ditingkatkan sehingga kualitas pengendalian menjadi semakin baik, dan kemampuannya untuk mendeteksi kesalahan/ kecurangan menjadi semakin baik pula, (Muliansah, 2020).

Penerapan e-puskesmas di Puskesmas Kota Barat dilihat dari aspek control termasuk dalam kategori krang baik yaitu e-puskesmas masih sering mengalami error, tidak terbebas dari virus atau mudah terinfeksi virus computer. Hal ini karena e-puskesmas membutuhkan jaringan internet sedangkan jaringan internet di Puskesmas Kota Barat masih kurang bagus dan jika jaringan internet mati akan mengakibatkan aplikasi e-puskesmas error. Hasil penelitian ini tidak sejalan dengan penelitian (Muliansah \& Budihartanti, 2020) yang menunjukan bahwa hasil Pemanfaatan e-Puskesmas di Loket Pendaftaran pada Puskesmas Kecamatan Pademangan, perhitungan jumlah rata- rata tingkat kepuasan diperoleh bernilai 4.16 pada domain control dan bila dipadukan dengan tingkat kepuasan menurut Kaplan dan Norton, maka dapat disimpulkan bahwa tingkat diperoleh rata-rata tingkat kepuasan berdasarkan domain kepuasan pengguna terhadap e-Puskesmas termasuk dalam kategori puas.

Efficiency ditujukan untuk menghasilkan output sebanyak-banyaknya dengan input seminimal mungkin (Fatta, 2007). Hasil penelitian menunjukkan bahwa dari aspek efficiency penerapan e-puskesmas di Puskesmas Kota Barat termasuk dalam kategori kurang baik, hal ini karena aplikasi e-puskesmas belum memberikan efisiensi tenaga karena tidak semua bidang di Puskesmas Kota Barat menggunakan e-puskesmas dan masih kekurangan tenaga kesehatan sehingga yang ditempatkan dalam pemegang program belum sesuai dengan fungsional. Hasil penelitian ini sejalan dengan penelitian (Inggarputri, 2009) yang menunjukkan bahwa hasil evaluasi penerapan sistem informasi manajemen puskesmas berbasis komputer di puskesmas wilayah Kabupaten Blora dari aspek efficiency dinilai belum memberikan efisiensi waktu dan tenaga.

Service merupakan analisis terhadap peningkatan pelayanan yang diberikan oleh sistem. Kriteria sistem dikatakan buruk jika sistem tersebut menghasilkan suatu produk yang tidak 
akurat, tidak konsisten, dan tidak bisa dipercaya (Fatta, 2007). Service yaitu untuk mengetahui bagaimana meningkatkan kepuasan pengguna sistem informasi tersebut, yang terdiri dari 3 aspek berikut. Akurasi, yaitu ketelitian komputasi dan kontrol. Reliabilitas, tingkat dimana sebuah program dapat dipercaya dan diandalkan untuk melakukan fungsi yang diminta. Kesederhanaan, yaitu tingkat di mana sebuah program dapat dipahami.

Hasil penelitian menunjukkan bahwa dari aspek service penerapan e-puskesmas di Puskesmas Kota Barat termasuk dalam kategori baik yaitu aplikasi e-puskesmas mudah digunakan, setiap submenu di menu pendaftaran dapat di akses dengan mudah, menggunakan fitur search/pencarian data pasien dan dilengkapi sistem pembetulan/pengupdatean data pasien. Hasil penelitian ini sejalan dengan penelitian (Muliansah \& Budihartanti, 2020) yang menunjukan bahwa hasil Pemanfaatan e-Puskesmas di Loket Pendaftaran pada Puskesmas

Kecamatan Pademangan, perhitungan jumlah rata- rata tingkat kepuasan diperoleh bernilai 3.99 pada domain Information dan bila dipadukan dengan tingkat kepuasan menurut Kaplan dan Norton, maka dapat disimpulkan bahwa tingkat diperoleh rata-rata tingkat kepuasan berdasarkan domain kepuasan pengguna terhadap e-Puskesmas termasuk dalam kategori puas.

\section{Kesimpulan}

Pemanfaatan layanan e-puskesmas di Puskesmas Kota Barat menggunakan metode PIECES, menunjukan bahwa aspek dengan kategori baik yaitu performance (51.7\%), information (55.2\%), dan service (55.2\%). Sementara itu, aspek dengan kategori kurang baik yaitu economics (51.7\%), control (72.4\%), dan efficiency (55.2\%). Disarankan kepada pihak Puskesmas Kota Barat disarankan untuk menerapkan layanan e-puskesmas sesuai dengan Keputusan Menteri Kesehatan No. 128/Menkes/SK/II/2014 tentang kebijakan dasar pusat kesehatan masyarakat.

\section{Referensi}

Dona, F., Susmiati, S., \& Murni, D. (2019). Efisiensi Perangkat Pendukung dalam Pelaksanaan Sistem Informasi e-Puskesmas Kota Sungai Penuh. Jurnal Ilmiah Universitas Batanghari Jambi, 19(3). https://doi.org/10.33087/jiubj.v19i3.724

Fatta, H. Al. (2007). Analisis dan Perancangan Sistem Informasi. ANDI.

Fikri, R. L. (2019). Evaluasi Penerapan Sistem Informasi Manajeman Puskesmas (SIMPUS) Melalui Metode Pieces Layanan Kunjungan Rawat Jalan Puskesmas Bogor Utara Tahun 2018. PROMOTOR, 2(4). https://doi.org/10.32832/pro.v2i4.2242

Fitriana, B. R. D., Hidana, R., \& Parinduri, S. K. (2020). Analisis Penerapan Sistem Informasi Manajemen Puskesmas (SIMPUS) Dengan Model Human Organization Technology (HOT)-FIT di Puskesmas Tanah Sareal Kota Bogor Tahun 2019. PROMOTOR, 3(1). https://doi.org/10.32832/pro.v3i1.3121

Haryani, D. S., \& Satriadi, S. (2019). Penerapan E-Puskesmas pada Puskesmas Tanjungpinang. Jurnal Penelitan Ekonomi Dan Bisnis, 4(2). https://doi.org/10.33633/jpeb.v4i2.2566

Inggarputri, Y. R. (2009). Evaluasi Penerapan Sistem Informasi Manajemen Puskesmas 
(SIMPUS) Berbasi Komputer dengan Metode PIECES di Puskesmas Wilayah Kabupaten Blora [Universitas Diponegoro]. http://eprints.undip.ac.id/38350/

Kepmenkes. (2014). Kebijakan Dasar Pusat Kesehatan Masyarakat. http://depkes.go.id

Maulana, Y. I., \& Salim, A. (2021). Evaluasi Penggunaan Supporting Applications For Quick Data Search (SuApQuDaS) Dengan Metode PIECES Framework. Jurnal Ilmiah Teknologi Informasi Asia, 15(1). https://doi.org/10.32815/jitika.v15i1.512

Muliansah, R., \& Budihartanti, C. (2020). Analisa Pemanfaatan e-Puskesmas di Loket Pendaftaran pada Puskesmas Kecamatan Pademangan dengan Metode PIECES. Journal of Computer Science and Engineering (JCSE), 1(1). https://doi.org/10.36596/jcse.v1i1.22

Pratiwi, A. E., \& Susanti, S. (2021). Evaluasi Kinerja Sistem Informasi Akuntansi Accurate Accounting Enterprise Menggunakan Metode PIECES. Jurnal Responsif: Riset Sains Dan Informatika, 3(1). https://doi.org/10.51977/jti.v3i1.402

Prayogi, R., Ramanda, K., Budihartanti, C., \& Rusman, A. (2021). Penerapan Metode PIECES Framework Dalam Analisis dan Evaluasi Aplikasi M-BCA. Jurnal Infortech, 3(1). https://doi.org/10.31294/infortech.v3i1.10122

Putra, H. N. (2018). Analisis Pelaksanaan Sistem E-Puskesmas Dengan Menggunakan Metode PIECES Di Puskesmas Pemancungan Padang Tahun 2018. Jurnal Rekam Medis Dan Informasi Kesehatan, 1(1).

Ramadhan, G., \& Kusumaningtyas, R. H. (2021). Analisis dan Perancangan Sistem Informasi Rekam Medis Puskesmas Jatilawang. Applied Information System and Management (AISM), 2(1). https://doi.org/10.15408/aism.v2i1.20209

Subektianto, R. A., Ratna, M., \& Zain, I. (2018). Analisis Kepuasan Pasien dan Pelaksana Terhadap Sistem Informasi Manajemen Puskesmas Elektronik (Simpustronik) di Kabupaten Blitar Menggunakan Regresi Logistik Biner. Inferensi, 1(1). https://doi.org/10.12962/j27213862.v1i1.6718

Sugiyono, D. (2018). Metode penelitian kuatintatif , kualitatif dan R \& D / Sugiyono. In Bandung: Alfabeta.

Widodo, F. (2013). Evaluasi Penerapan Sistem Informasi Manajemen Puskesmas (SIMPUS) di Kabupaten Bantul. Universitas Gadjah Mada.

Wulandari, R. (2009). Evaluasi Kinerja Sistem Informasi Manajemen Puskesmas Berbasis Komputer di Wilayah Kerja Dinas Kesehatan Kota Semarang [Universitas Diponegoro]. http://eprints.undip.ac.id/3907/ 